\title{
Silent Ischemic Heart Disease in a Patient with Necrotizing Glomerulonephritis due to Wegener's Granulomatosis
}

\author{
Daniel Salazar-Exaire ${ }^{a} \quad$ Manolo Ramos-Gordillo ${ }^{a} \quad$ Jorge Vela-Ojeda ${ }^{a}$ \\ Celia Elena Salazar-Cabrerac Magdalena Sanchez-Uribe ${ }^{b}$ \\ Maria Consuelo Calleja-Romerob \\ ${ }^{a}$ Clinical Epidemiology Research Unit and ${ }^{b}$ Department of Pathology, Hospital de \\ Especialidades, Centro Médico La Raza, Instituto Mexicano del Seguro Social, and 'Facultad de \\ Medicina UNAM D.F., Mexico City, Mexico
}

\section{Key Words}

Necrotizing glomerulonephritis - Wegener's granulomatosis • Silent myocardial infarction •

Coronary vasculitis

\begin{abstract}
Objective: Wegener's granulomatosis (WG) is a necrotizing vasculitis that mainly affects the respiratory tract and kidneys, but can also affect other systems such as the eye, joints, skin, muscles, nerves, and gastrointestinal tract. Cardiac involvement is traditionally believed to be rare. We report a patient with silent myocardial infarction (MI) and review previously reported cases showing this association. Methods: A Medline database search of cases published between January 1978 and July 2008 both in English and Spanish, reporting silent MI complicating WG, was conducted. Results: We describe a typical patient with WG who had both respiratory and renal involvement and died unexpectedly following a silent $\mathrm{Ml}$ after a period of clinical improvement induced by treatment with prednisone and cyclophosphamide. We report necropsy findings and the association with 5 additional cases of WG with silent MI reported in the literature. Conclusions: Clinicians should be aware of potential cardiac involvement due to WG. Careful evaluation of each patient, with or without cardiac symptoms, using ECG, echocardiogram, and myocardial enzymes is prudent.

Copyright $\odot 2012$ S. Karger AG, Basel
\end{abstract}




\section{CardioRenal Medicine}

Cardiorenal Med 2012;2:218-224

\begin{tabular}{l|l}
\hline DOI: $10.1159 / 000339551$ & (c) 2012 S. Karger AG, Basel
\end{tabular} Published online: July 19, 2012 www.karger.com/crm

Salazar-Exaire et al.: Silent Ischemic Heart Disease in a Patient with Necrotizing Glomerulonephritis due to Wegener's Granulomatosis

\section{Introduction}

Wegener's granulomatosis (WG) is a necrotizing granulomatous vasculitis that mainly affects the upper and lower respiratory tract and kidneys [1]. Since the first description of the disease in 1931 [2,3], numerous case reports and reviews have documented other end-organ involvement, underscoring the disseminated nature of this disease.

Cardiac involvement in WG, including subclinical forms, is not as rare as previously considered, ranging between 6 and 44\% of cases [4]. The high range is associated with more advanced disease and a higher rate of postmortem examinations [5]. Interestingly, Morelli et al. [6] recently reported results of 9 patients with WG without known cardiac involvement who all proved to have abnormalities during transthoracic echocardiographic examination.

In this report, we describe a patient with both respiratory and renal involvement who died unexpectedly following a silent myocardial infarction (MI) after a period of clinical improvement induced by treatment with cyclophosphamide and prednisone. In this context, we review the previous literature dealing with the association between necrotizing glomerulonephritis (WG) and silent cardiac implications, with special emphasis on the relationship between both processes.

\section{Methods}

A literature review from January 1966 to July 2008 was performed using Medline (PubMed). Cases with coexisting WG and silent MI were searched. Only 5 cases published in either English or Spanish were found for review.

\section{Case Report}

We report the case of a 22-year-old male who was admitted to the Nephrology Department of La Raza Medical Center, Instituto Mexicano del Seguro Social, Mexico City, for the first time in September 2007 with an 8-month history of nasal congestion and 2-month history of painful lower extremities, dizziness, fever, fatigue, arthralgia, coughing, and dark urine. The patient's history was otherwise negative except for arterial hypertension for 1 year before admission, for which captopril was prescribed but sporadically taken. In addition, during the previous week the patient reported redness of his left eye, ear pain, and nasal discharge of 'bloody' mucus. He had noticed increasing nocturia from 1 to at least 3 or 4 episodes each night. Despite a 1-week course of antibiotic treatment for sinusitis, there was no respiratory tract improvement. The patient reported no previous significant medical history except for longstanding sensitivity to sunlight. There was no relevant family history. Although the patient was afebrile, clinical examination demonstrated the patient to be in poor health. He was in severe pain due to swollen joints and multiple vasculitic lesions over the feet and face. His right foot was cold with an absent dorsalis pedis pulse. There was no lymphadenopathy, hepatomegaly or splenomegaly. His pulse rate was 115/ min, blood pressure (BP) 150/90 mm Hg and there were normal sounds with no murmurs. Auscultation of the lung fields revealed only normal breath sounds. Laboratory analysis demonstrated hemoglobin of $10 \mathrm{~g} / \mathrm{dl}$ and white blood count of $14 \times 10^{9} / \mathrm{l}$. Urea was $68 \mathrm{mg} / \mathrm{dl}$ and creatinine $2.4 \mathrm{mg} / \mathrm{dl}$. Urine testing revealed blood and protein with a creatinine clearance of $44 \mathrm{ml} / \mathrm{min}$. Erythrocyte sedimentation rate was $110 \mathrm{~mm} / \mathrm{h}$ and C-reactive protein was $140 \mathrm{mg} / \mathrm{dl}$. Anti-neutrophil cytoplasmic antibodies were positive at a titer of 1:320 with a cytoplasmic staining pattern by ELISA on purified antigen. Anti-nuclear antibody, rheumatoid factor, and anti-glomerular basement membrane were negative. Electrocardiogram (ECG) was normal and echocardiogram revealed no abnormality other than tachycardia. A biopsy of the patient's nasal tissue was performed, demonstrating granulomatous tissue with necrosis and inflammation with eosinophils, lymphocytes, and some giant cells; C3, C4, and IgG were negative by immunochemistry staining.

A diagnosis of WG was made and immunosuppressive treatment was begun. The patient was given three 1-gram i.v. pulses of methylprednisolone on alternate days followed by $60 \mathrm{mg}$ of oral predniso- 


\section{CardioRenal Medicine}

Fig. 1. ECG showing changes of a recent extensive anterior and inferior MI. A repeat ECG showed the changes of a recent extensive anterior myocardial infarct with established Q waves (b). A review of the ECG carried out on admission confirmed that this trace was normal (a).

\begin{tabular}{|c|c|}
\hline Cardiorenal Med 2012;2:218-224 & \\
\hline $\begin{array}{l}\text { DOI: } 10.1159 / 000339551 \\
\text { Published online: July 19, } 2012\end{array}$ & $\begin{array}{l}\text { ( } 2012 \text { S. Karger AG, Basel } \\
\text { www.karger.com/crm }\end{array}$ \\
\hline
\end{tabular}
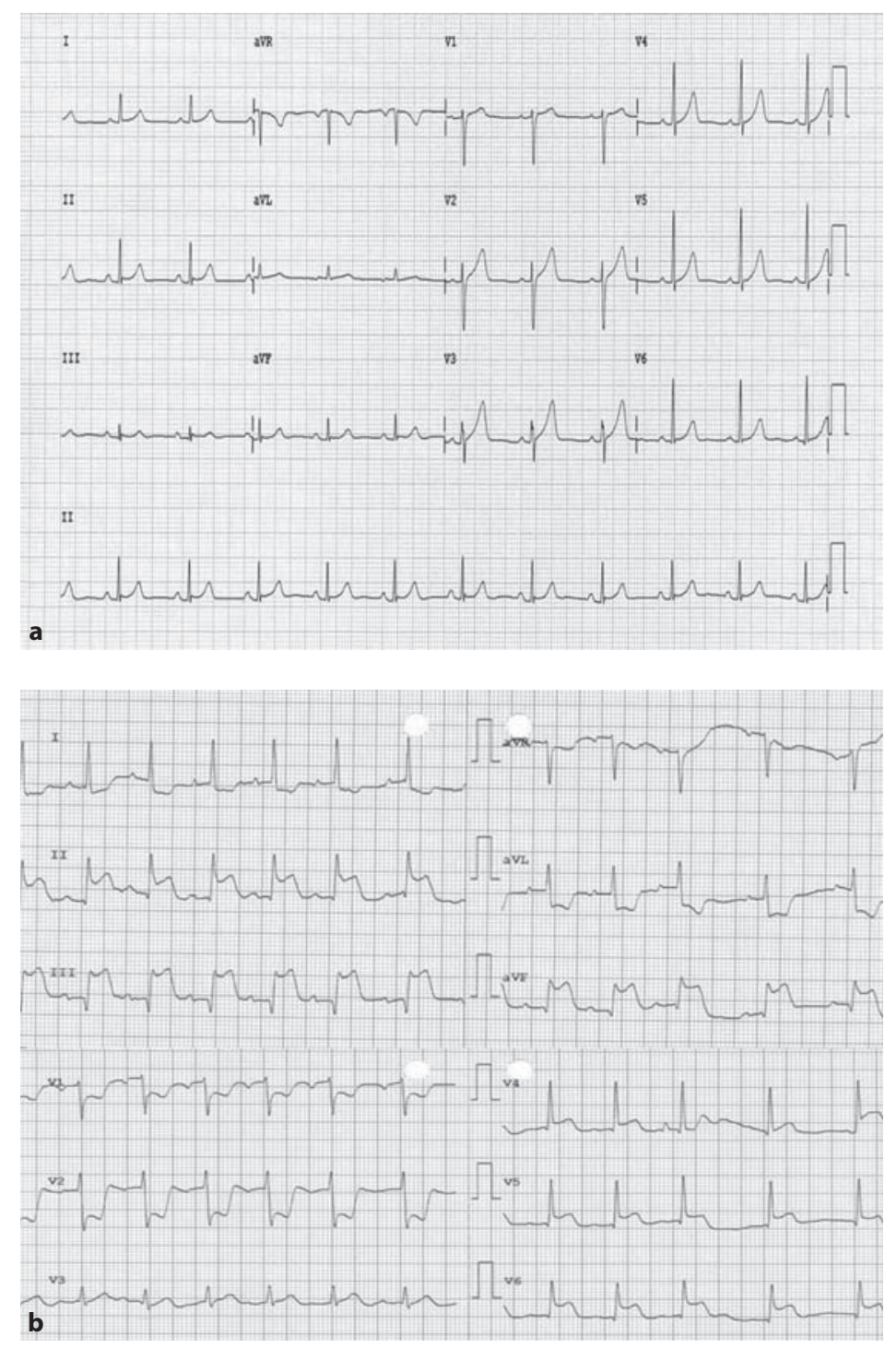

lone and $150 \mathrm{mg}$ of cyclophosphamide daily. He also underwent a course of plasma exchange totaling 26 liters and, in addition, was transfused with $2 \mathrm{U}$ of packed cells. His clinical status improved within $72 \mathrm{~h}$. The vasculitic skin lesions on the feet and face and dorsalis pedis pulses began to resolve and no new lesions appeared. Erythrocyte sedimentation rate decreased to $40 \mathrm{~mm} / \mathrm{h}$ after 2 days and continued to decrease. After 1 week, C-reactive protein was $12 \mathrm{mg} / \mathrm{l}$. The patient remained mildly hypertensive (BP 130/90 $\mathrm{mm} \mathrm{Hg}$ ) and, in view of the persistent tachycardia, a cardiology consultation was sought. This confirmed the presence of a sinus tachycardia with an otherwise normal ECG and no evidence of cardiac disease. Glutamic pyruvic transaminase, glutamic oxaloacetic transaminase, and creatine kinase (CK) were normal.

Three weeks after initiation of immunosuppressive therapy, the patient's condition suddenly deteriorated. His pulse rate increased to $140 / \mathrm{min}$ and was associated with hypotension (BP 90/60 $\mathrm{mm} \mathrm{Hg}$ ) and a gallop rhythm. A repeat ECG showed acute anterior and acute inferior wall Q-wave infarctions, with anterior infarct, ST elevation in leads II and aVL and the precordial leads, accompanied by reciprocal ST depressions in leads III and aVF (fig. 1b; admission ECG shown in fig. 1a). Echocardiography showed septal akinesia and diffuse hypocontractility without dilatation of the left ventricle. Silent acute anterior and inferior wall MI was diagnosed. CK concentration was $340 \mathrm{U} / 1$ with CK isoenzyme MB 174 U/1. At no time 


\section{CardioRenal Medicine}

Fig. 2. Necrotizing glomerulonephritis with extracapillary proliferation and epithelial crescents (H/E; original magnification $\times 400$ ).

Fig. 3. Histology of left coronary artery obliterated by necrotizing arteritis and occlusive vasculitic thrombosis with inflammatory and necrotizing fibrinoid granulomata. The destructive inflammation is eccentric, transmural and has destroyed the inner and outer elastic lamina $(\mathrm{H} / \mathrm{E}$; original magnification $\times 100$ ).

\begin{tabular}{l|l}
\hline Cardiorenal Med 2012;2:218-224 \\
\hline DOI: $10.1159 / 000339551$ \\
Published online: July 19, 2012 & $\begin{array}{l}\text { @ 2012 S. Karger AG, Basel } \\
\text { www.karger.com/crm }\end{array}$ \\
\hline
\end{tabular}

Salazar-Exaire et al.: Silent Ischemic Heart Disease in a Patient with Necrotizing Glomerulonephritis due to Wegener's Granulomatosis
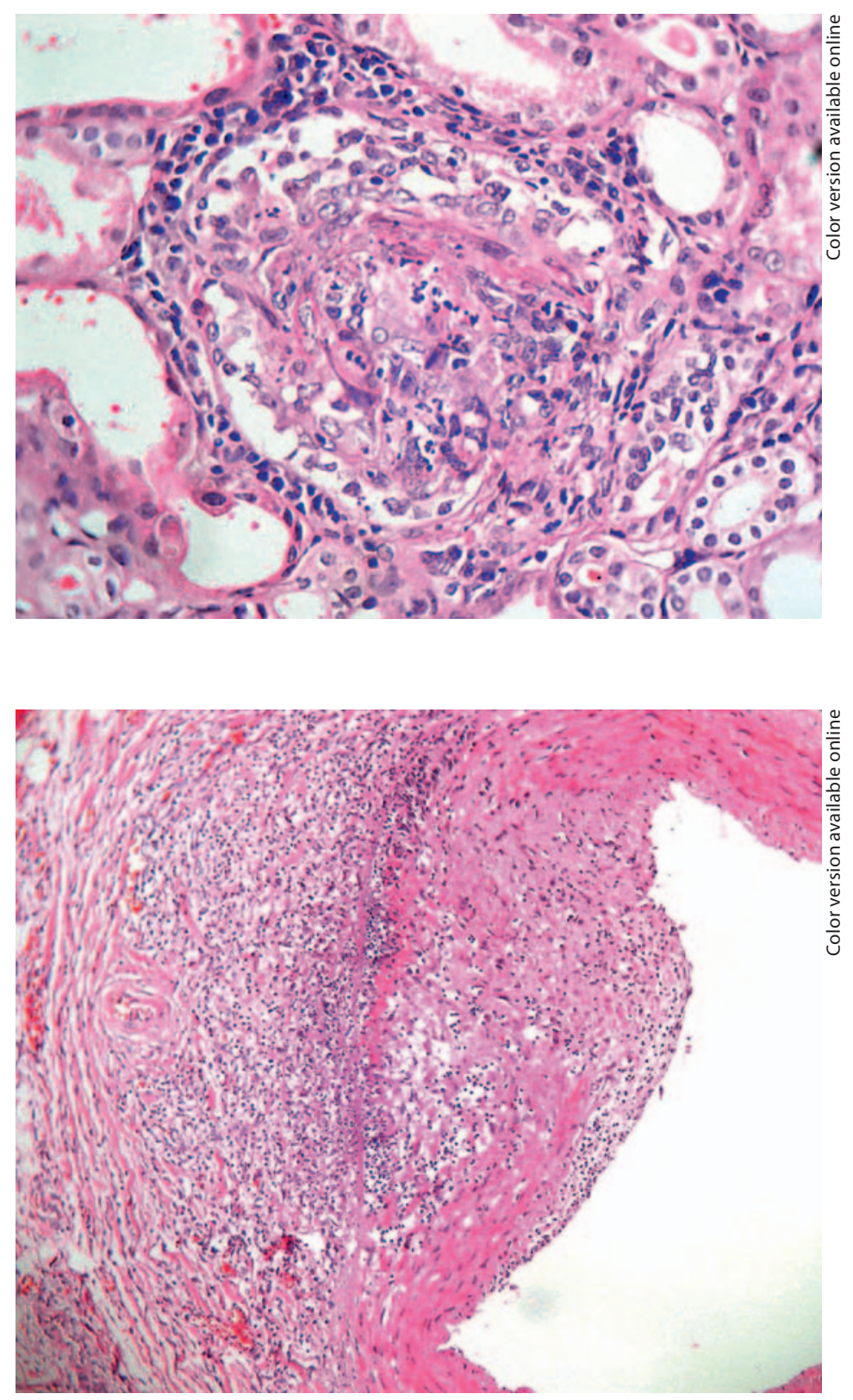

did the patient complain of chest pain. Despite maximal inotropic support, the patient's clinical evolution demonstrated worsening cardiogenic shock. He died 3 days later. Permission for postmortem examination was given.

\section{Necropsy Findings}

Necropsy confirmed a severe and disseminated necrotizing granulomatosis affecting the lungs, kidneys, spleen, skin, and heart. A florid systemic vasculitic component was present in these organs, in the aorta, and in its main distributing branches. Pulmonary arterioles showed a florid transmural and fibrinoid vasculitis with a heavy infiltrate of polymorphonuclear leucocytes, vessel wall necrosis, and giant cells. Kidney cortices were pale, and microscopy showed extensive necrotizing glomerulitis with fibrin aggregates and exudates of polymorphonuclear leucocytes. This heavy inflammation was centered on the glomeruli and radiated to the surrounding interstitium. Capsular epithelial crescents were present (fig. 2). Intrarenal vessels of all sizes were acutely inflamed and fibrinoid in appearance, and there was papillary necrosis. 


\section{CardioRenal Medicine}

\begin{tabular}{|c|c|}
\hline Cardiorenal Med 2012;2:218-224 & \\
\hline $\begin{array}{l}\text { DOI: } 10.1159 / 000339551 \\
\text { Published online: July 19, } 2012\end{array}$ & $\begin{array}{l}\text { ( } 2012 \text { S. Karger AG, Basel } \\
\text { www.karger.com/crm }\end{array}$ \\
\hline
\end{tabular}

Purpura noted on clinical examination correlated with an acute vasculitic process in the dermis and subcutaneous fat. Splenic vessels were affected, resulting in multiple recent infarcts in the enlarged spleen $(380 \mathrm{~g})$. The heart weighed $540 \mathrm{~g}$, and there was fibrinous pericarditis. Microscopy showed the endocardia of both atria were thickened and inflamed with foci of fibrinoid necrosis and a palisading granulomatous reaction of inflammatory cells. Similarly, foci were present in the epicardium, base of the mitral valve, and myocardium of the proximal interventricular septum where giant cells were present. Coronary arteries demonstrated focally inflamed intima with acute anteroseptal MI with occlusive vasculitic thrombosis of the left coronary artery. Microscopy showed diffuse vasculitis and inflammatory and necrotizing fibrinoid granulomata (fig. 3).

Aortic intima and iliac arteries were affected by this granulomatous vasculitis, and the right posterior tibial artery and vein were occluded, secondary to vasculitic thrombosis.

\section{Discussion}

WG, a systemic inflammatory disorder of unknown cause, is a necrotizing and granulomatous vasculitis that usually affects the upper and lower respiratory tract and kidneys [7, 8]. Cardiac involvement is generally thought to be rare, although ECG abnormalities, coronary artery vasculitis, cardiac arrhythmias, pericarditis, myocarditis, valvulitis, and MI have been described [9-11]. In aggregate, histopathological studies demonstrated 30\% incidence of cardiac involvement. The pericardium was the most common site of this involvement occurring in $50 \%$ of cases, with the other $50 \%$ involving the coronary arteries. Pericardial pathology has demonstrated diffuse, as well as focal, areas of involvement. Pericardial effusions and cardiac tamponade have been reported $[4,7]$. The endocardium (including valves), myocardium, and epicardium are also targets of the vasculitic process. The epicardium has shown granulomatous inflammatory foci $[4,7]$ and the myocardium has shown granulomatous foci, perivascular inflammation and necrotizing arteriolitis. The endocardium and valves were also involved in several cases with inflammation, fibrinoid necrosis, and granulomatous formation of the mitral and, less commonly, tricuspid valves [7, 12]. Although the incidence of the cardiac conduction system in WG patients has not been investigated, it appears that atrial and supraventricular arrhythmias are more common than ventricular arrhythmias $[4,7]$.

Coronary vasculitis has been reported in $\sim 50 \%$ of autopsy cases of WG in which the heart was examined at autopsy.

Clinical manifestations such as angina pectoris and MI are uncommon [7, 11]. The coronary vessels showed a spectrum of vasculitic stages from acute necrotizing activity to healing stages. Other potential mechanisms of ischemia include coronary artery embolism from contiguous aortic valvulitis [13,14] and aortitis-related ostial stenosis [14]. The association of WG with MI in living subjects has been described in several series $[8,9,11,12,15]$. Notably, in 5 of these cases, as in our case, there were no chest complaints $[8,9,11,12,16]$ (table 1) despite typical manifestations of WG. Five of the cases were fatal, suggesting that MI in these patients carries a dismal prognosis. The true frequency of these abnormalities, however, is difficult to establish because the proportion of cases subjected to detailed postmortem histological examination is variable.

Literature concerning cardiac involvement and immunosuppressive therapy with cyclophosphamide is limited and controversial; in some cases, immunosuppressive therapy allowed a complete resolution of the cardiac lesion $[17,18]$ was largely due to the relatively high incidence of MI, particularly in those with advanced age at the time of diagnosis, in males, and in those treated with high doses of cyclophosphamide $[9,11]$. This study confirmed the results of previous reports, indicating that patients with WG frequently experience 'silent' MI, which may further contribute to an increase of mortality rates. 


\section{CardioRenal Medicine}

\begin{tabular}{|c|c|}
\hline Cardiorenal Med 2012;2:218-224 & \\
\hline $\begin{array}{l}\text { DOI: } 10.1159 / 000339551 \\
\text { Published online: July 19, } 2012\end{array}$ & $\begin{array}{l}\text { (c) } 2012 \text { S. Karger AG, Basel } \\
\text { www.karger.com/crm }\end{array}$ \\
\hline
\end{tabular}

Table 1. Silent ischemic heart disease in patients with necrotizing glomerulonephritis due to Wegener's granulomatosis: review of the literature

\begin{tabular}{|c|c|c|c|c|}
\hline Reference & $\begin{array}{l}\text { Gender/ } \\
\text { age (years) }\end{array}$ & $\begin{array}{l}\text { Renal } \\
\text { involvement }\end{array}$ & Postmortem studies & Outcome \\
\hline \multicolumn{5}{|l|}{ Papo et al. [11] } \\
\hline Case 1 & $\mathrm{M} / 42$ & Yes & No & Recovery \\
\hline Case 2 & $\mathrm{~F} / 41$ & Yes & No & Recovery \\
\hline $\begin{array}{l}\text { Lawson and Williams } \\
\text { [9] }\end{array}$ & $\mathrm{M} / 23$ & Yes & No & Death \\
\hline Parry et al. [12] & $\mathrm{M} / 26$ & Yes & Occlusive coronary vasculitic thrombosis & Death \\
\hline De la Prada et al. [8] & $\mathrm{M} / 34$ & Yes & $\begin{array}{l}\text { Posteroinferior transmural infarct } \\
\text { without evidence of coronary vasculitis }\end{array}$ & Death \\
\hline $\begin{array}{l}\text { Salazar-Exaire et al. } \\
\text { (present study) }\end{array}$ & $\mathrm{M} / 22$ & Yes & $\begin{array}{l}\text { Anteroseptal infarct with evidence of } \\
\text { occlusive vasculitic thrombosis of the } \\
\text { left coronary artery }\end{array}$ & Death \\
\hline
\end{tabular}

Our case is atypical in that cardiac complications occurred several days after treatment initiation at a time when the patient's clinical status showed improvement and the only manifestation was persistent tachycardia in the absence of fever and associated with arterial hypotension. The reason for such an extensive anteroseptal infarct without symptoms is unknown. In fact, the acute event in this patient was not diagnosed until the development of cardiogenic shock, and a different clinical outcome is unlikely had the infarct been diagnosed earlier.

Table 1 shows all characteristics of the 6 reported cases in the literature of silent ischemic heart disease in patients with glomerulonephritis due to WG.

Several similarities have been observed in all cases:

(1) MI was the first cardiac manifestation.

(2) MI was not associated with previous chest pain despite classical renal manifestations of WG.

(3) There were diffuse cases of WG.

(4) MI may occur even after clinical improvement with specific treatment.

(5) No coronary injuries were associated with hemodynamic repercussions.

(6) MI was not associated with risk factors for atherosclerotic heart disease.

(7) MI was fatal in all cases.

(8) In those cases with postmortem studies, coronary vasculitis with inflammation, fibrinoid necrosis of the intima, and occlusion with intraluminal mural thrombosis in coronary vessels independently of atheromatous plaque were demonstrated.

In conclusion, there is convincing evidence that, in contrast to traditional teaching, the heart is frequently affected in necrotizing glomerulonephritis due to WG, presenting a variety of manifestations: either subtle, subclinical or atypically symptomatic. In particular, these manifestations included pericarditis, myocarditis, arrhythmias, and silent coronary events. We report an unusual timing of cardiac manifestation - a case of silent ischemic heart disease with glomerulonephritis due to WG, occurring after initiation of anti-vasculitic treatment. 


\section{CardioRenal Medicine}

\begin{tabular}{|c|c|}
\hline Cardiorenal Med 2012;2:218-22 & \\
\hline $\begin{array}{l}\text { DOI: } 10.1159 / 000339551 \\
\text { Published online: July 19, } 2012\end{array}$ & $\begin{array}{l}\text { (c) } 2012 \text { S. Karger AG, Basel } \\
\text { www.karger.com/crm }\end{array}$ \\
\hline
\end{tabular}

Clinicians should be aware of the potential cardiac involvement in WG, and each patient should be carefully evaluated by ECG, echocardiogram, and myocardial enzymes, even in the absence of cardiac symptoms.

\section{Acknowledgement}

This study was supported by grants (2005/1/I/117 and 2005/1/I/178) from FOFOI-IMSS (Mexico). We acknowledge the editorial assistance of Alejandra Perez Gomez.

\section{Disclosure Statement}

The authors have no conflicts of interest.

\section{References}

1 Fauci AS, Wolff SM: Wegener's granulomatosis: studies in eighteen patients and a review of the literature. Medicine (Baltimore) 1973;52:535-561.

2 Klinger H: Grenzformen der Periarteritis nodosa. Frankfurt Z Path 1931;42:455-480.

3 Wegener F: Über generalisierte, septische Gefässerkrankungen. Verh Dtsch Ges Pathol 1936;29:202-210.

4 Korantzopoulos P, Papaioannides D, Siogas K: The heart in Wegener's granulomatosis. Cardiology 2004;102:7-10.

5 Grant SC, Levy RD, Venning MC, Ward C, Brooks NH: Wegener's granulomatosis and the heart. Br Heart J 1994;71: $82-86$.

6 Morelli S, Gurgo Di Castelmenardo AM, Conti F, Sgreccia A, Alessandri C, Bernardo ML, et al: Cardiac involvement in patients with Wegener's granulomatosis. Rheumatol Int 2000;19:209-212.

7 Forstot JZ, Overlie PA, Neufeld GK, Harmon CE, Forstot SL: Cardiac complications of Wegener granulomatosis: a case report of complete heart block and review of the literature. Semin Arthritis Rheum 1980;10:148-154.

8 De la Prada FJ, Prados A, Ramos R, Munar MA, Losada P, Morey A: Silent ischemic heart disease in patient with Wegener's necrotizing glomerulonephritis (in Spanish). Nefrologia 2003;23:545-549.

-9 Lawson TM, Williams BD: Silent myocardial infarction in Wegener's granulomatosis. Br J Rheumatol 1996;35:188191.

10 Watts RA: Wegener's granulomatosis: unusual presentations. Hosp Med 2000;61:250-253.

$\checkmark 11$ Papo T, Piette JC, Laraki R, Bletry O, Huong DL, Godeau P: Silent myocardial infarction in Wegener's granulomatosis. Ann Rheum Dis 1995;54:233-234.

12 Parry SD, Clark DM, Campbell J: Coronary arteritis in Wegener's granulomatosis causing fatal myocardial infarction. Hosp Med 2000;61:284-285.

13 Gerbracht DD, Savage RW, Scharff N: Reversible valvulitis in Wegener's granulomatosis. Chest 1987;92:182-183.

14 Iwatani H, Nagasawa Y, Oka K, Isaka Y, Imai E: Valvular injury in a patient with PR3-ANCA-associated glomerulonephritis. Nat Clin Pract Nephrol 2008;4:576-582.

15 Allison SJ: Vasculitis: renal involvement in granulomatosis with polyangiitis - role of ANCA isotype and Fc receptor genotype. Nat Rev Nephrol 2012;8:63.

16 Kelley JM, Monach PA, Ji C, Zhou Y, Wu J, Tanaka S, Mahr AD, Johnson S, McAlear C, Cuthbertson D, Carette S, Davis JC Jr, Dellaripa PF, Hoffman GS, Khalidi N, Langford CA, Seo P, St Clair EW, Specks U, Stone JH, Spiera RF, Ytterberg SR, Merkel PA, Edberg JC, Kimberly RP: IgA and IgG antineutrophil cytoplasmic antibody engagement of Fc receptor genetic variants influences granulomatosis with polyangiitis. Proc Natl Acad Sci USA 2011;108:2073620741.

17 Cocco G, Gasparyan AY: Myocardial ischemia in Wegener's granulomatosis: coronary atherosclerosis versus vasculitis. Open Cardiovasc Med J 2010;23:57-62.

18 Geerdink LM, Koster-Kamphuis L, Cornelissen EA, Willemsen MA, van de Kar NC: Unexplained hypothermia and bradycardia in two pediatric patients with Wegener's granulomatosis. Pediatr Nephrol 2011;26:325-326. 